\title{
Jornalismo: Uma literatura sob pressão
}

OLINTO, Antônio. Jornalismo e Literatura. Porto Alegre: JÁ Editores, 2008. 92p.

Por Vaniucha de Moraes

O jornalismo é uma literatura do imediato, sujeito às pressões do tempo e do espaço. Ainda que seu modus operandi seja condicionado pelos horários de fechamento e limitado pelo espaço, este conserva as mesmas possibilidades da literatura de produzir obras de arte. Esta afirmação abre a obra ensaística Jornalismo $e$ Literatura, de Antônio Olinto, publicada originalmente em 1955, e relançada em 2008. O ensaio de Olinto surge num período marcado pela implantação de uma imprensa moderna e industrial no Brasil, com a promoção de reformas gráficas e editoriais que preconizaram uma separação instrumental e ideológica entre o fazer jornalístico e o fazer literário.

\section{ANTONIO OLINTO}

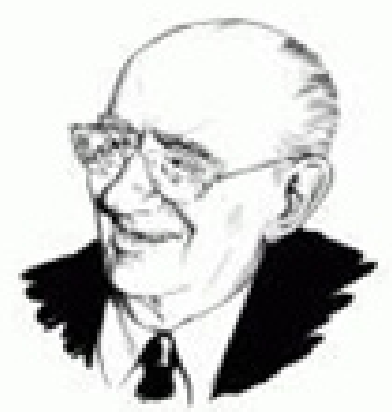

Jornalismo e Literatura

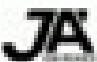

Essas transformações são mencionadas no transcorrer do livro, mesmo que de forma indireta, em passagens em que ressalta a existência de um jornalismo ancorado na efemeridade. Para o autor, o jornalismo é uma contínua luta pela fixação de realidades, uma tentativa de captar nos acontecimentos cotidianos algumas verdades particulares e permanentes de vida do homem - a conexão direta com as questões sociais mais pungentes (p. 17). Esse engajamento com as questões populares não significa panfletarismo, mas que o jornal possui o mesmo potencial da literatura para atingir o intelecto dos leitores e, ao fazê-lo, perdurar como experiência cognitiva.

\section{Jornalismo como Literatura}

Olinto reúne vários argumentos que associam o jornalismo à literatura.

Sobre a autora

Vaniucha de Moraes é Mestranda em Jornalismo pela Universidade Federal de Santa Catarina. vaniucha1@yahoo.com.br Logo no primeiro capítulo, indica que a pressão é comum tanto à literatura quanto ao jornalismo. A diferença é que o escritor vivencia com mais liberdade o ato de criação e a pressão advém dele mesmo ou da necessidade de chegar ao fim da obra. O trabalho é regido pela imprevisibilidade da inspiração. Como o jornalismo é uma literatura para o consumo imediato, de caráter efêmero, possui funcionalidade e esquematização próprias. Assim, a pressão é dupla: de tempo e de espaço. O jornalista tem menos liberdade 
de criação devido as condições e sistematizações do trabalho.

Para que o jornalismo se configure como um gênero literário é preciso que o jornalista compreenda o que é notícia. "Notícia, mensagem, reportagem é tudo o que, insuflando-se nas palavras, busca comunicação" (p. 15). Por isso, o importante é fazer da notícia um elemento capaz de permanecer. Tanto o escritor como o jornalista têm como matéria-prima é a palavra. "O que serve de caminho para a poesia também transmite a morte de uma criança” (p. 15). A base da literatura de ficção é a realidade. Porém, o jornalismo trabalha com a realidade em ato e a literatura com a realidade em potência. Mas ambos se sujeitam às leis da descrição e da narrativa.

Sobre o sentido da reportagem, o autor destaca a especificidade do repórter e o seu íntimo contato com a realidade. A reportagem é a função específica do jornal, seu essencial. O repórter de rua faz muito mais jornalismo do que o autor de um artigo de fundo. Jornalismo e poesia, porém, não podem ser associados porque o primeiro busca uma aproximação direta com os fatos, enquanto a segunda a relação com o real é feita de forma muito peculiar de lidar com as palavras, seus sentidos e suas sonoridades.

A permanente prisão ao imediato e à transitoriedade são perigos à capacidade de percepção dos temas mais pungentes da sociedade. O espírito de organização do jornalismo pode comprometer a atividade criadora levando-o à aridez interior (p. 20). Olinto indica que a diferença entre o jornalismo comum e o jornalismo como arte é que o escritor deixa-se corromper pelo trabalho diário de escrever e pelos perigos da organização. Assim, esquece que é preciso manter a capacidade de sentir e transmitir sentimentos estranhamente verdadeiros (p. 21).

\section{Independência}

Antônio Olinto dedica várias páginas para reafirmar a potencialidade literária contida no jornalismo. Para tanto, cita autores cujas obras são referências do bom jornalismo com possibilidade de superação e eternidade, entre eles Graham Greene, Chesterton e o brasileiro Euclides da Cunha.

A relação entre literatura, enquanto romance, e jornalismo já foi tema de ensaio de W. Benjamin. Para ele, o surgimento da modernidade e do modo de produção industrial capitalista teriam ocasionado uma crise nas formas tradicionais de transmissão de conhecimento, isto é, a morte da narrativa tradicional, baseada em experiências vívidas e compartilhadas. As sociedades modernas teriam adotado o romance e o jornalismo, que são narrativas centradas na solidão tanto de quem produz como de quem apreende o conteúdo. Na obra de Antônio Olinto percebese que autor faz uma alusão a um tipo de jornalismo distinto do
O jornalismo trabalha com a realidade em ato e a literatura com a realidade em potência. Mas ambos se sujeitam às leis da descrição e da narrativa 
criticado por Benjamin. Anseia o ensaísta que o jornalismo seja a transmissão de um conteúdo informativo, centrado para além da efemeridade e que contemple a vivência do repórter com riqueza narrativa e descritiva.

Alguns tipos de reportagem surpreendem pela densidade informativa e riqueza descritiva, o que evidencia que são características pertinentes também no universo jornalístico. Em 'obras literárias' como Os sertões, Hiroshima e Os dez dias que abalaram o mundo pode-se constatar que é possível produzir um jornalismo de qualidade.

O ensaio de Antônio Olinto é perspicaz ao antever a importância de determinadas questões para o jornalismo. Considerandose que é obra datada, remonta a uma época em que as teorias sobre jornalismo no Brasil ainda eram insipientes. Isso demonstra o caráter visionário de Olinto e a característica emancipadora de sua obra, o que já lhe assegura uma recomendação.

Recebido em 2 de março de 2009 Aprovado em 2 de maio de 2009 